\title{
SISTEM PERADILAN DI INDONESIA ${ }^{1}$ \\ Oleh Patawari ${ }^{2}$
}

Peradilan berasal dari kata adil, artinya segala sesuatu mengenai perkara pengadilan dalam lingkup negara Indonesia. Indonesia merupakan negara hukum. Hal ini ditegaskan dalam Pasal 1 ayat (3) UUD 1945 Perubahan ke-4 disebutkan bahwa: "Negara Indonesia adalah negara hukum" Ketentuan pasal tersebut merupakan landasan konstitusional bahwa Indonesia adalah negara yang berdasarkan atas hukum, hukum ditempatkan sebagai satu-satunya aturan main dalam kehidupan bermasyarakat, berbangsa dan bernegara (supremacy of law). Penegakan hukum di Indonesia tidak terlepas dari sistem peradilan.

Sistem peradilan di Indonesia adalah keseluruhan perkara pengadilan dalam suatu negara yang satu sama lain berbeda tetapi saling berkaitan atau berhubungan sehingga terbentuk suatu mekanisme dan dapat diterapkan secara konsisten. Dalam sistem peradilan di indonesia. Beberapa unsur pihak yang terlibat di dalam di antaranya:

1. Penyidik adalah pejabat polisi negara RI atau pejabat PNS tertentu yg diberikan wewenang khusus oleh Undang Undang untuk melaksanakan penyidikan (Pasal 1 angka 1 KUHAP). Selain penyidik sebagai pihak yang yang terkait dalam sistem peradilan di Indonesia, dalam hukum ada yang disebut penyidikan, penyelidik, penyelidikan. Penyidikan adalah serangkaian tindakan penyidik dalam hal dan menurut cara yg diatur dalam Undang Undang untuk mencari serta mengumpulkan bukti yg dgn bukti itu membuat terang tetang tindak pidana yg terjadi dan guna menemukan tersangkanya (pasal 1 angka 2 KUHAP). Penyelidik adalah pejabat polisi negara RI yg diberi wewenang oleh UU untuk melakukan penyelidikan (pasal 1 angka 4 KUHAP). Penyelidikan adalah serangkaian tindakan penyelidik untu mencari dan menemukan suatu peristiwa yg diduga sebagai tindak pidana guna menetukan dpt atau tdknya dilakukan penyidikan menurut cara yg diatur dlm UU ( pasal 1 angka 5 KUHAP)

2. Penuntut umum, (jaksa)

3. hakim,

4. penasihat hukum ${ }^{3}$, dan

1 Dr. Patawari, SHI.,MH. 2017 "Sistem Peradilan Di Indonesia" Pendidikan Khusus Provesi Advokat (PKPA) DPN PERADI kerjasama Universitas Sawerigading Makassar, Sabtu 11 Pebruari 2017 Fakultas Hukum Universitas Sawerigading Makassar.

2 Lahir Bone, 15 Mei 1981 Jenjang Studi S1. UIN Alauddin Makasar. S2. HTN UNHAS. S3. HTN Unhas. Pengalaman Pengajar: UIT Makassar, UIN Alauddin Makassar, STIK Makassar, STIK Tamalate, Polinas Makassar, IAIN palopo, STIH Manokowari, AKPER Makassar, Amik Makassar. Jabatan Direktur IndoWACANA (lembaga Pengkajian, Penelitian dan perancanagn Peraturan Perundang Undangan dan Kebijakan Pemerintah), Ka.prodi Hukum UIT, Wakil dekan Hukum UIT, WD II Hukum UIT. E-Mail: patawari.dr@gmail.com Cp. 081355081182 


\section{Pencari keadilan.(Pengacara)}

Perbedaan Peradilan dan Pengadilan yakni Peradilan adalah suatu proses yang dijalankan di pengadilan yang berhubungan dengan tugas memeriksa, memutus dan mengadili perkara. Sedangkan pengadilan adalah badan atau instansi resmi yang melaksanakan sistem peradilan berupa memeriksa, mengadili, dan memutus perkara.

Negara Indonesia sebagai negara hukum mempunyai tugas menjalankan suatu sistem peradilan yang jujur (berdasarkan hati nurani dan keyakinan), adil ( tanpa memihak pada kelompok atau golongan tertentu/membenarkan yg benar menyalahkan yg salah tanpa ada intervensi dri pihak manapun) dan bersih dari korupsi(perbuatan yg menyahgunakan kompotensi yg dimiliki), kolusi (bentuk kerjasama antara pejabat pemerintah dengan oknum lain secara ilegal pula atau melanggar hukum untuk mendapatkan keuntungan material) , nepotisme (pemanfaatan jabatan untuk memberi pekerjaan, kesempatan, atau penghasilan, bagi keluarga atau kerabat dekat pejabat, sehingga menutup kesempatan bagi orang lain).

Adapun asas yang harus digunakan dalam sistem peradilan di negara Indonesia adalah sebagai berikut:

1. Asas asas dalam Praktik Peradilan Perdata.

Asas-asas hukum yang sering dijumpai adalah sebagai berikut :

a. Asas "Ius Curia Novit"

"setiap hakim dianggap tahu akan hukumnya", sehingga tidak ada alasan bagi hakim untuk menolak suatu perkara yang diajutkan kepadanya dengan daalil bahwa hakimnya tidak tahu hukumnya atau hukumnya belum ada.

b. Asas peradilan cepat,(efisien) singkat (efektif) dan biaya ringan (tidak memberatkan)

Asas ini mulai diatur dalam ketentuan pokok kekuasaaan hakim.

c. Asas Audi Et Alterram Partem

"mendengar kedua belah pihak yang berpekara". Dalam asas ini menitik beratkan pada pengertian bahwa hakim diwajibkan untuk tidak memutus perkara sebelum mendengar kedua belah pihak terlebih dahulu.

d. Asas Unus Testis Nullus Testis

"satu saksi bukanlah saksi"

e. Asas tidak ada keharusan untuk mewakilkan kepada pengacara.

Tidak mengatur secara tegas bahwa untuk perkara di pengadilan harus diwakilkan kepada seorang pengacara.

f. Asas Nemo Judex Indeneus in Propria Causa.

Asas ini mengajarkan bahwa tidak seorang pun yang dapat menjadi hakim dalam perkara sendiri. Dalam hukum acara perdata, asas ini

\footnotetext{
${ }^{3}$ Perbedan Kuasa hukum; pada ranah perdata, Dimana Penggugat tergugat bisa tidak hadir. Penasihat hukum; apda ranah pidana, oleh karena perkara dijalankannya maka tidak dapat diwakilinya, dan pelakukan wajib hadir, karena suatu perbutan dak dapat dikuasakan, sehingga hanya dapat didampingin.
} 
menekankan pada obyektifitas pada pemeriksaan perkar. Tentunya asas ini ditunjukkan kepada hakim bahwa seorang hakim karena jabatannya harus mengundurkaan diri dari kedudukannya dalam memeriksa suatu perkara yang diajukan kepadanya bilamana ia mempunyai kepentingan langsung terhadap tersebut atau mempunyai hubungan keluarga yang dekat dengan salah satu pihak yang berperkara.

g. Asas Lex Rae Sitae

Bahwa suatu gugatan diajukan di tempat nama obyek gugatan itu berada dan bukan di tempat tinggal penggugat.

2. Asas asas dalam Praktik Peradilan pidana

a. Perlakuan yang sama dimuka hukum, tanpa diskriminasi apapun;

b. Asas praduga tak bersalah;

c. Hak untuk memperoleh kompensasi (ganti rugi) dan rehabilitasi Hak untuk memperoleh bantuan hukum;

d. Hak kehadiran terdakwa di muka pengadilan;

e. Peradilan yang bebas dan dilakukan dengan cepat dan sedehana;

f. Peradilan yang terbuka untuk umum;

g. Pelanggaran atas hak-hak warga negara (penangkapan, penahanan, pengeledahan dan penyitaan) harus didasarkan pada undang-undang dan dilakukan dengan surat perintah (tertulis);

h. Hak seseorang tersangka untuk diberikan bantuan tentang prasangkaan dan pendakwaan terhadapnya;

i. Kewajiban pengadilan dan mengendalikan putusannya.

Tujuan penyelenggaraan peradilan nasional adalah menegakkan hukum dan keadilan. Perihal penyelenggaraan peradilan di indonesia antara lain diatur dalam Undang-Undang Nomor 4 Tahun 2004 tentang Kekuasaan Kehakiman. Kekuasaan kehakiman adalah kekuasaan yang merdeka untuk menyelenggarakan peradilan guna menegakkan hukum dan keadilan berdasarkan Pancasila demi terselenggaranya negara hukum Republik Indonesia.

Penyelenggaraan kekuasaan kehakiman dilakukan oleh sebuah Mahkamah Agung dan badan peradilan yang berada di bawahnya:

- lingkungan peradilan umum,

- lingkungan peradilan agama,

- lingkungan peradilan militer,

- lingkungan peradilan tata usaha negara, dan

Meskipun di Indonesia terdapat 4 (empat) lingkungan peradilan, akan tetapi Konstitusi juga memberikan kesempatan untuk dibuatnya pengadilan khusus yang berada di bawah masing-masing badan peradilan tersebut 4 (empat) lingkungan peradilan di Indonesia berdasarkan Pasal 24 ayat (2) UUD 1945, antara lain: 
1. Lingkungan Peradilan Umum, meliputi sengketa perdata (perjanjian jual beli, wanprestasi, dll) dan pidana (pembunuhan, pencurian dll)

2. Lingkungan Peradilan Agama, meliputi hukum keluarga seperti perkawinan, perceraian, dan lain-lain. Undang-Undang yang mengatur mengenai Pengadilan Agama yakni UU Nomor 7 Tahun 1989 tentang Peradilan Agama, yang bertugas dan berwenang untuk memeriksa, memutus, dan menyelesaikan perkaraperkara di tingkat pertama antara orang-orang yang beragama Islam dibidang perkawinan, waris, wasiat, hibah, wakaf dan shadaqoh, dimana keseluruhan bidang tersebut dilakukan berdasarkan hukum Islam.

3. Lingkungan Peradilan Tata Usaha Negara, meliputi sengketa antar warga Negara dan pejabat tata usaha Negara. Undang-Undang yang mengatur mengenai Pengadilan Tata Usaha Negara (PTUN) yakni UU Nomor 5 Tahun 1986 yang telah diamandemen dengan UU Nomor 9 Tahun 2004 tentang Peradilan Tata Usaha Negara. Pengadilan ini berwenang menyelesaikan sengketa antar warga Negara dan Pejabat Tata Usaha Negara. Objek yang disengketakan dalam Peradilan Tata Usaha Negara yaitu keputusan tata usaha Negara yang dikeluarkan oleh pejabat tata usaha Negara. Dan dalam Peradilan Tata Usaha Negara ini terdapat 2 (dua) macam upaya hukum ${ }^{4}$, antara lain yakni Upaya Administrasi, yang terdiri dari banding administrasi dan keberatan, serta Gugatan.

4. Lingkungan Peradilan Militer, hanya meliputi kejahatan atau pelanggaran yang dilakukan oleh militer. Undang-Undang yang mengatur mengenai Pengadilan Militer yakni UU Nomor 31 Tahun 1997 tentang Peradilan Militer. Pengadilan ini berwenang mengadili kejahatan atau pelanggaran yang dilakukan oleh militer.

Adapun terhadap Pengadilan Khusus di Indonesia, telah terdapat 6 (enam) Pengadilan Khusus yang masing-masing memiliki kewenangannya sendiri sebagaimana dijelaskan berikut dibawah ini, antara lain :

1. Pengadilan Niaga, dibentuk dan didirikan berdasarkan Keputusan Presiden RI Nomor 97 Tahun 1999. Kewenangan Pengadilan Niaga antara lain adalah untuk mengadili perkara Kepailitan, Hak atas Kekayaan Intelektual, serta sengketa perniagaan lainnya yang ditentukan oleh Undang-Undang.

2. Pengadilan HAM, dibentuk dan didirikan berdasarkan Undang-Undang Nomor 26 Tahun 2000. Kewenang Pengadilan HAM adalah untuk mengadili pelanggaran HAM berat, sebagaimana yang pernah terjadi atas kasus

\footnotetext{
${ }^{4}$ Istilah Upaya hukum kerap di jumpai pada Upaya hukum Biasa dimana ranahnya adalah pada PN, PT bentuk pengujiannya dalah menggunakan hingga MA Judex facti. Upaya hukum Luar Biasa pengujiannya dalah judex juris seperti PK (ketika ada bukti baru)
} 
pelanggaran hak asasi berat di Timor-Timur dan Tanjung Priok pada Tahun 1984. Pelanggaran hak asasi tersebut tengah mengeluarkan Keputusan Presiden Nomor 53 Tahun 2001 atas pembentukan Pengadilan Hak Asasi Manusia Ad Hoc di Pengadilan Negeri Jakarta Pusat, yang saat ini diubah melalui Keputusan Presiden Nomor 96 Tahun 2001.

3. Pengadilan Anak, dibentuk dan didirikan berdasarkan Undang-Undang Nomor 3 Tahun 1997, yangmana merupakan implementasi dari Konvensi Hak Anak yang telah diratifikasi, bahwa setiap anak berhak atas perlindungan, baik terhadap eksploitasi, perlakuan kejam dan perlakuan sewenang-wenang dalam proses peradilan pidana. Dan Yurisdiksi Peradilan Anak dalam hal perkara pidana adalah mereka yang telah berusia 8 tetapi belum mencapai 18 Tahun.

4. Pengadilan Pajak, dibentuk dan didirikan berdasarkan Undang-Undang Nomor 14 Tahun 2002, dan memiliki yurisdiksi menyelesaikan sengketa di bidang pajak. Sengketa pajak sendiri merupakan sengketa yang timbul dalam bidang perpajakan antara wajib pajak atau penanggung pajak dan pejabat yang berwenang sebagai akibat dikeluarkannya keputusan yang dapat diajukan banding atau gugatan kepada Pengadilan Pajak berdasarkan peraturan perundang-undangan perpajakan, termasuk didalamnya gugatan atas pelaksanaan penagihan berdasarkan Undang-Undang penagihan pajak dengan surat paksa.

5. Pengadilan Perikanan, dibentuk dan didirikan berdasarkan Undang-Undang 31 Tahun 2004. Peradilan ini berwenang memeriksa, mengadili, dan memutus tindak pidana di bidang perikanan, dan berada di lingkungan Peradilan Umum dan memiliki daerah hukum sesuai dengan daerah hukum pengadilan negeri yang bersangkutan.

6. Pengadilan Khusus Tindak Pidana Korupsi, dibentuk dan didirikan berdasarkan amanat Pasal 53 Undang-Undang Nomor 30 Tahun 2002 tentang Komisi Pemberantasan Tindak Pidana Korupsi. Pengadilan ini memiliki yurisdiksi untuk menangani perkara korupsi dan berkedudukan di jakarta.

Selain itu dalam sistem peadilan ada dua tingkatan peradilan berdsarkan cara pengambilan keputusan yaitu judex facti dan judex juris Pengadilan Negeri dan Pengadilan Tinggi judex facti ayng berwewenang memeriksa fakta hukum dan dan bukti perkara. Mahkamah Agung adalah judex juris, hanya memeriksa penerapan hukum dari suatu perkara, dan tidak memeriksa fakta dari perkaranya. 